\title{
Bioinspired bactericidal surfaces with polymer
}

\section{nanocone arrays}

\author{
Gavin Hazell ${ }^{\ddagger}$, Leanne E. Fisher ${ }^{¥}$, W. Andrew Murray ${ }^{\S}$, Angela H. Nobbs ${ }^{¥}$ and Bo Su ${ }^{¥ *}$ \\ ${ }^{¥}$ School of Oral and Dental Sciences, University of Bristol, Bristol BS1 2LY, United Kingdom \\ $\S$ School of Physics, University of Bristol, Bristol BS8 1TL, United Kingdom
}

Keywords: Biomaterials, nanotopography, bioinspired, bactericidal, nanocone.

\begin{abstract}
Infections resulting from bacterial biofilm formation on the surface of medical devices are challenging to treat and can cause significant patient morbidity. Recently, it has become apparent that regulation of surface nanotopography can render surfaces bactericidal. In this study, poly(ethylene terephthalate) nanocone arrays are generated through a polystyrene nanosphere-mask colloidal lithographic process. It is shown that modification of the mask diameter leads to a direct modification of centre-to-centre spacing between nanocones. By altering the oxygen plasma etching time it is possible to modify the height, tip width and base diameter of the individual nanocone features. The bactericidal activity of the nanocone arrays was investigated against Escherichia coli and Klebsiella pneumoniae. It is shown that surfaces with the most densely populated nanocone arrays (center-to-center spacing of $200 \mathrm{~nm}$ ), higher aspect ratios and (>3) tip widths $<20 \mathrm{~nm}$ kill the highest percentage of bacteria $(\sim 30 \%)$.
\end{abstract}




\section{Introduction}

The use of implanted medical devices is an essential part of modern medicine. Upon implantation a "race to the surface ensues, in which eukaryotic and prokaryotic cells compete for surface colonisation ${ }^{1}$. If microbes are the dominant cell they will aggregate at the tissueimplant interface, self-producing extracellular polymeric substances (EPS), which facilitates cell-cell and cell-surface interactions. This process is commonly referred to as biofilm formation. Biofilm-associated infections of implanted medical devices are difficult to treat as microbial cells within the interior of the biofilm are less susceptible to host defences and/or antibiotics $^{2}$. These infections can have devastating consequences including implant failure, sepsis and, in extreme cases, death ${ }^{3}$.

Considerable research efforts have been placed on designing surfaces that inhibit the development of biofilms. This has led to approaches using two key strategies. The first is to chemically modify surfaces with known biocidal substances ${ }^{4}$. These have included antibiotics ${ }^{5}$, ${ }^{6}$, heavy metal nanoparticles ${ }^{7,8,9}$, polymers ${ }^{10,11,12}$ and enzymes/peptides ${ }^{13,14,15,16}$. However, chemical approaches have disadvantages as they may introduce toxic materials into the host ${ }^{17}$ and/or lead to sub-critical concentration exposure ${ }^{18}$ which may result in the development of antimicrobial resistance ${ }^{19}$.

The second approach uses purely physical cues by altering surface nanotopography. High aspect ratio nanofeatures are used to control microbial growth in a surface chemistryindependent manner with a physico-mechanical mechanism ${ }^{20,21}$. These surfaces offer a safer alternative for biofilm prevention by presenting unfavourable surface nanotopography that either kills bacteria upon contact (bactericidal) or prevents microbial attachment (antibiofouling). Most often, these nanostructured surfaces are modelled on the hierarchical formations of nanofeatures observed in nature such as insect wings (cicada ${ }^{22}$, damselfly ${ }^{23}$, 
dragonfly ${ }^{24}$ ), shark skin ${ }^{25}$ and the lotus leaf ${ }^{26}$. Ivanova et al first studied the adhesive behaviour of Pseudomonas aeruginosa (P. aeruginosa) cells on the surface of the Psaltoda claripennis cicada wing ${ }^{22}$. These surfaces possess periodic spherically capped, conical, nanoscale pillars. The nanopillars are $200 \mathrm{~nm}$ in height, $100 \mathrm{~nm}$ in diameter at the base and $60 \mathrm{~nm}$ at the cap with inter-pillar spacing of $170 \mathrm{~nm}$. P. aeruginosa cells were found to adhere in large numbers however, biofilm formation was prevented as the high-aspect-ratio nanopillars physically disrupted the bacteria cells upon attachment. Hasan $e t a l^{27}$ furthered these studies showing that the nanostructure of the wing surface was able to consistently kill Gram negative bacteria, independent of bacterial shape. However, Gram positive cells remained resistant. Theoretical studies have demonstrated that bacterial cell adhesion onto the nanopillar surface acts to stretch the cell membrane in the regions between nanofeatures with a high dependency on the nanofeature spatial orientation ${ }^{28}$. Kelleher et $a l^{29}$ have compared the wing bactericidal performance of a number of cicadae species towards the Gram negative bacteria, Pseudomonas fluorescens ( $P$. fluorescens). This demonstrated that bactericidal efficacy increases as the number of nanopillars with which the bacteria cells contact increases. This is also in agreement with mathematical models proposed by Xue et $a l^{30}$ which suggest that short-sharp nanopillars induce the greatest strain on bacterial membranes and higher levels of killing. Therefore, it is vital that the spatial orientation of nanofeatures at the interface is studied and optimized to induce maximum bactericidal efficacy.

To this end, a large number of biomimetic analogues have been investigated. These have largely focused on nanopatterning biocompatible materials such as titanium ${ }^{31,32,33,34}$, titania ${ }^{35}$, graphene $^{36}$, diamond ${ }^{37,38}$ and polymeric materials ${ }^{39,40}$. Nanopatterning techniques employed have been diverse including plasma etching ${ }^{38}$, laser ablation ${ }^{41}$, nano-imprint lithography ${ }^{42}$, alkaline hydrothermal methods ${ }^{33}, 35$ and reactive-ion-etching ${ }^{41}$. One promising colloidal technique is mask-assited lithography or colloidal lithography ${ }^{43}$ in which polystyrene or silica 
microspheres are deposited onto a polymeric surface. The surface is then subjected to a reactive ion etching procedure and exposed areas in between the mask are preferentially etched, leading to the formation of high-aspect-ratio nanopillars ${ }^{44}$. Liu et al have fabricated poly(ethylene terephthalate) (PET) nanocone arrays with inter-cone spacing of $500 \mathrm{~nm}^{45}$. Dickson et al fabricated poly(methyl methacrylate) (PMMA) nanopillars with varying degrees of inter-pillar spacing and slightly different pillar heights. They concluded that short, closely spaced nanopillars showed greater bactericidal efficacy towards Escherichia coli (E. coli) compared to nanopillars spaced more widely apart ${ }^{42}$. This study aims to expand upon the previously reported PET nanocone structures by modifying spatial orientation through colloidal lithography, using polystyrene microspheres as the mask with differing diameters $(200 \mathrm{~nm}$ and $500 \mathrm{~nm}$, process shown schematically in figure 1 as part of the materials and methods section). This results in final nanocone spaings of $200 \mathrm{~nm}$ and $500 \mathrm{~nm}$, corresponding to a surface with nanofeatures with similar spacing to those found on the cicada wing surface along with an additional comparison for nanofeatures spaced more widely apart. The bactericidal activity of these surfaces is then tested against examples of opportunistic pathogens; E. coli K12 and Klebsiella pneumoniae, clinical isolate (kindly provided by Matt Avison) (K. pneumoniae) in an attempt to elucidate more information with regard to bactericidal efficacy and nanofeature spatial orientation. 


\section{Experimental}

\section{Materials}

PET films with a thickness of $0.2 \mathrm{~mm}$ were purchased from Goodfellow, U.K and cut into 2.0 x $2.0 \mathrm{~cm}$ substrates. Adsorbed surface impurities were removed by ultrasonic cleaning in acetone (Fisher, $98 \%$ ) and de-ionised water (purified to a resistivity of $18 \mathrm{M} \Omega \mathrm{cm}^{-1}$ ). PET substrates were then rinsed with ethanol (Sigma-Aldrich, $96 \%$ ) several times and dried with a nitrogen $\left(\mathrm{N}_{2}\right)$ stream. PET substrates were immersed overnight in a $3 \mathrm{wt} \%$ sodium dodecyl sulphate (SDS, Sigma-Aldrich, $98 \%$ ) solution to improve wettability and facilitate polystyrene (PS) microsphere spreading.

PS microspheres with diameters of $500 \mathrm{~nm}$ or $200 \mathrm{~nm}$ were purchased from Sigma-Aldrich as an aqueous suspension with $10 \mathrm{wt} \%$ solids.

\section{Fabrication of PET nanocone arrays}

PET nanocone arrays were fabricated through colloidal lithography ${ }^{46}$. PS microspheres were self-assembled on the surface of the cleaned PET substrates by spin coating. $100 \mu \mathrm{L}$ of a 0.5 wt \% PS microsphere (500 nm or $200 \mathrm{~nm}$ ) dispersion in 1:1 (vol/vol) water:ethanol was deposited onto the PET surface. The dispersion was allowed to spread evenly over the surface for ca. 20 seconds. The PS spheres were then spin-coated at $3600 \mathrm{rpm}$ for 1 minute using a photo-resist spin coater (Headway Research Inc., U.K, model PWM32). Subsequently surfaces were annealed in an oven at $55{ }^{\circ} \mathrm{C}$ for 2 hours to further encourage the formation of hexagonally close packed PS sphere monolayers on the surface.

PET nanocone arrays with different aspect ratios were achieved by subjecting the surfaces to inductively coupled plasma-reactive ion etching (ICP-RIE) using an ICP-RIE system (Oxford Instruments, U.K, model 100 ICP 180). Surfaces were etched in oxygen $\left(\mathrm{O}_{2}\right)$ at 15 
mTorr, a flow rate of $20 \mathrm{sccm}$, an RF power of $30 \mathrm{~W}$, an ICP power of $30 \mathrm{~W}$ for time durations of 5-20 minutes. This procedure is shown schematically in figure 1 . The figure also highlights the nanofeature dimensions that are measured after the etching process. PET nanocone surfaces were imaged using a Helios Nanolab 600 FIB-scanning electron microscope (SEM). Surfaces were mounted onto carbon stubs and sputtered twice with a mixture of gold/palladium for 1 minute per coating. Surface morphology was then measured using imaging software by analysing 15 different regions on the sample surface.

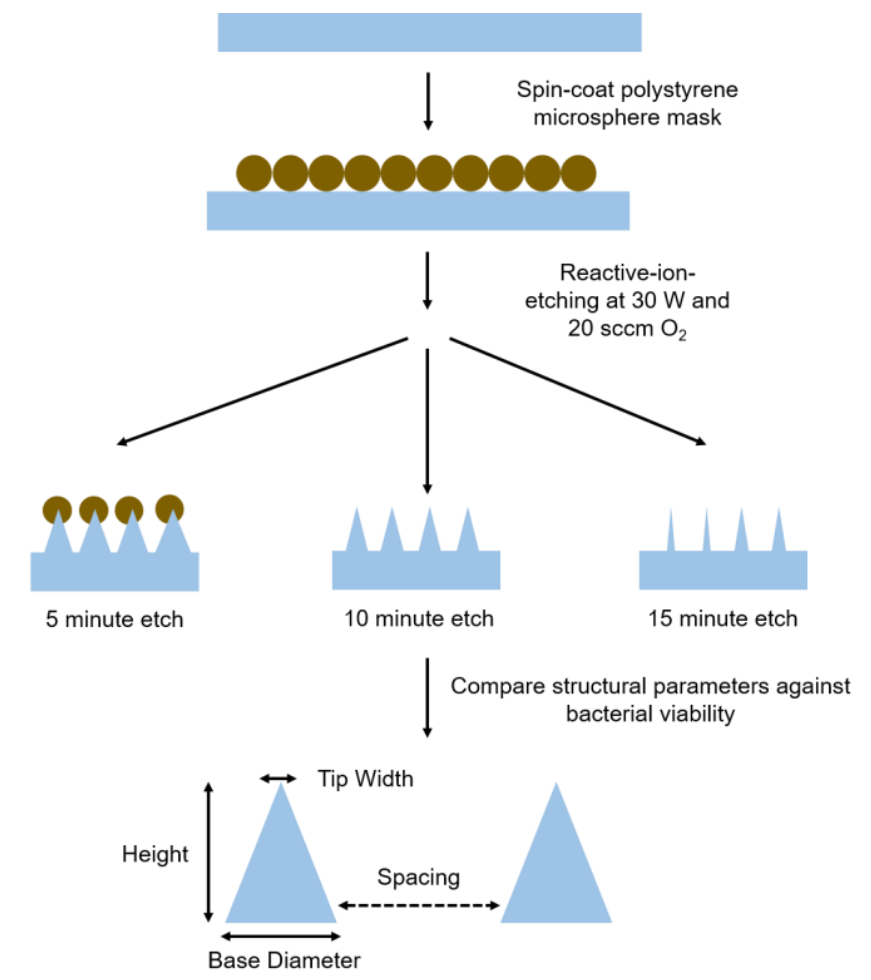

Figure 1- Schematic representation of the mask assisted colloidal lithographic process adopted in this study.

\section{Contact Angle Measurements}

The surface wettability of the PET substrates after each functionalisation step was measured. Contact angle measurements were conducted on a DSA100 drop shape analyzer (Kruss instruments, Hamburg). A small water droplet (2-3 $\mu \mathrm{l})$ was advanced on the surface using a 
motorized syringe. Kruss instrument software was used to measure the static tangent angle at the three-phase boundary. Contact angles were measured at three points on each surface. All tests were carried out in triplicate.

\section{Bacterial culture preparation}

E. coli K12 (ER2925, New England Biolabs) and K. pneumoniae (clinical isolate, kindly provided by M. Avisson), were grown aerobically for 16 hours in $15 \mathrm{ml}$ of Tryptic Soy Broth (TSB, E. coli) or Mueller-Hinton (MH, K. pneumoniae) in a $37{ }^{\circ} \mathrm{C}$ shaker incubator set at 220 $\mathrm{rpm}$. The bacterial suspension was then diluted into the relevant media to $\mathrm{OD}_{600} 0.1$ and further incubated until mid-exponential phase was reached. Bacterial cells were then harvested by centrifugation ( 7 minutes, $5000 \mathrm{~g}$ ), washed twice in $10 \mathrm{mM}$ Tris- $\mathrm{HCl}$ buffer, and suspended in Tris- $\mathrm{HCl}$ to $\mathrm{OD}_{600} 0.3$ (approximately $10^{7} \mathrm{cfu} \mathrm{ml}^{-1}$ ).

\section{Bacterial adhesion}

All test and control surfaces were rinsed with $70 \%$ ethanol prior to bacterial adhesion studies. Surfaces were placed into a 12-well microtiter plate and submerged in $2 \mathrm{ml}$ of bacterial suspension. Plates were incubated for 1 hour at $37{ }^{\circ} \mathrm{C}$ under static conditions. After incubation, surfaces were rinsed to remove non-adherent bacteria by gently holding the surfaces with a pair of tweezers and passing back and forth five times in a uniform manner into a Universal container containing Tris- $\mathrm{HCl}$ buffer.

\section{Live/Dead staining and fluorescence microscopy}

After rinsing, $1 \mathrm{ml}$ of Live/Dead® ${ }^{\circledR}$ acLight $^{\mathrm{TM}}$ bacterial viability stain was applied to the surfaces according to manufacturers' instructions. The surfaces were incubated in the dark for 15 minutes at room temperature and rinsed in Tris- $\mathrm{HCl}$ in the same manner as described above. Bacterial cell viability was then visualized by fluorescence microscopy using a Leica DMLB 
microscope and Leica acquisition software. ImageJ software was used to calculate the number of cells with intact membranes (SYTO 9, green) and the number of cells with damaged membranes (propidium iodide, red) based on a minimum of three images per surface. The average percentage of damaged cells was determined and all tests were carried out in triplicate. A one-way ANOVA was carried out to compare data sets. If the $p$ value was less than 0.05 , then results were considered statistically significant.

The live/dead procedure is carried out with extreme caution and attempts to ensure accurate, repeatable methodology are of paramount importance. It is however, accepted that rinsing the surface using the previously described manner may introduce certain experimental error. This is discussed in previously published work by Busscher et $\mathrm{l}^{47}$.

\section{Results and Discussion}

\section{Fabrication and tailorable aspect ratio of PET nanocone arrays via colloidal lithography} and reactive ion etching

PET nanocones were fabricated through colloidal lithography and reactive ion etching. Figure 1 shows a schematic representation of this process. Initially a two-dimensional hexagonally close packed array of PS microspheres was formed on the surface of the cleaned PET substrates via spin coating. Figure 2 shows the hexagonally close packed structure of the PS colloidal mask for both $500 \mathrm{~nm}$ and $200 \mathrm{~nm}$ PS microspheres. It is clear that the area of the hexagonally close packed spheres can reach many hundreds of $\mu \mathrm{m}^{2}$. 

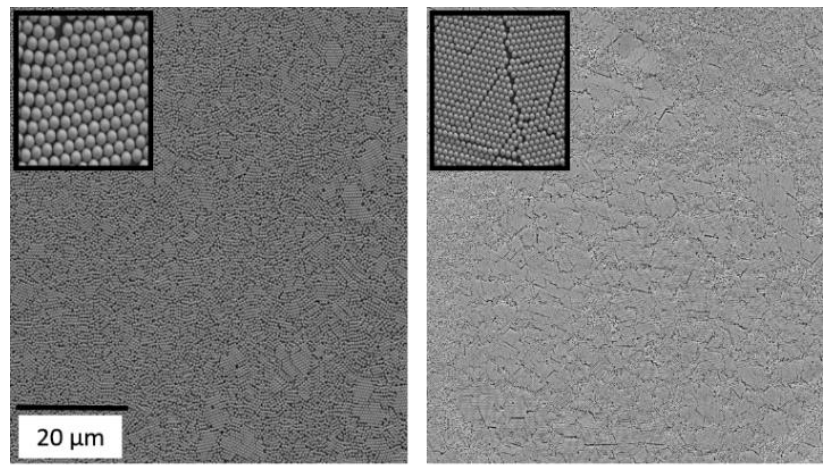

Figure 2- SEM images showing deposition of colloidal mask using $500 \mathrm{~nm}$ (left) or $200 \mathrm{~nm}$ (right) PS microspheres via spin coating.

Subsequently the 2D colloidal crystal mask was etched in oxygen using an ICP-RIE system. It has previously been reported that the final structure of etched nanocone arrays (formed through colloidal lithography) is heavily dependent on the duration of the etching process ${ }^{48}$. To assess the effects of the duration of the etching process on nanocone formation, the PS colloidal mask for both $200 \mathrm{~nm}$ and $500 \mathrm{~nm}$ PS spheres was subjected to 4 different etching times and characterised by SEM. Figure 3 shows SEM images of the PET structures obtained after $5,10,15$ or 20 minutes etching. Table 1 shows structural parameters for nanocones with differing colloidal masks and etching times.
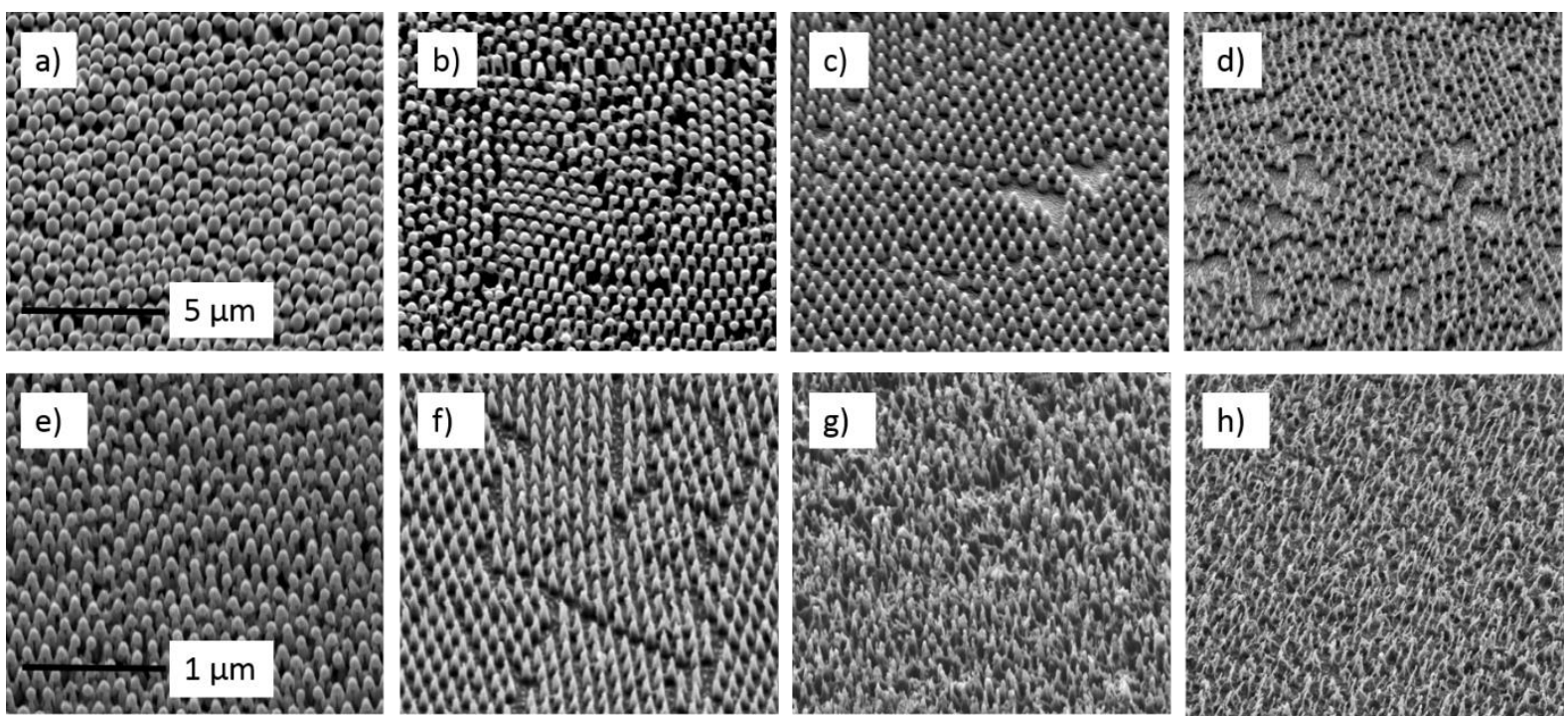
Figure 3- SEM images of PET nanocone structures obtained for a $500 \mathrm{~nm}$ (a-d) or $200 \mathrm{~nm}$ (ef) PS colloidal mask after 5, 10, 15 or 20 minutes etching time. Time duration increases for each colloidal mask sample from left to right.

\begin{tabular}{|c|c|c|c|c|c|c|c|c|}
\hline & \multicolumn{6}{|c|}{ Colloidal Mask Diameter (nm) } \\
\hline \multirow{3}{*}{ Structural Parameter } & \multicolumn{4}{|c|}{500} & \multicolumn{5}{c|}{200} \\
\cline { 2 - 9 } & \multicolumn{3}{|c|}{ Etching Time (mins) } & \multicolumn{4}{c|}{ Etching Time (mins) } \\
\cline { 2 - 9 } & 5 & 10 & 15 & 20 & 5 & 10 & 15 & 20 \\
\hline Base Diameter $(\mathrm{nm})$ & 381 & 316 & 272 & 187 & 155 & 129 & 118 & 55 \\
\hline Tip Width $(\mathrm{nm})$ & 304 & 280 & 193 & 99 & 54 & 33 & 22 & 20 \\
\hline Nanocone height $(\mathrm{nm})$ & 419 & 456 & 529 & 441 & 352 & 388 & 498 & 400 \\
\hline
\end{tabular}

Table 1- Structural parameters of PET nanocones obtained from a $500 \mathrm{~nm}$ or $200 \mathrm{~nm}$ PS colloidal mask after 5, 10, 15 and 20 minutes of etching time.

With increasing etching time the diameter of the PET nanocone structures decreases and the region in between the nanostructures becomes larger. When using the $500 \mathrm{~nm}$ PS colloidal mask and low etching times ( 5 or 10 minutes), the region between the nanostructures is very small due to only partial etching of the colloidal mask. Therefore, these structures have a domelike morphology. On increasing the etching time the colloidal mask is almost fully removed, exposing more PET to the oxygen plasma. Here, nanofeatures are isolated from their nearest neighbours and the features begin to show a cone-like morphology. For 5-15 minutes etching the trend is to increase in height. After 20 minutes etching time, the nanostructures still maintain an isolated cone-like morphology, but now the height begins to decrease. This is due to complete removal of the PS colloidal mask, meaning that the PET itself is now being heavily etched, yielding nanostructures that are lower in height. When using the $200 \mathrm{~nm}$ PS colloidal mask, cone formation occurs at lower etching times (after 10 minutes). This is due to the use of a colloidal mask with a lower diameter, which is etched at a faster rate than the larger 500 nm diameter mask ${ }^{45}$. Colloidal mask removal and isolated conical structures are obtained after 
10 minutes of oxygen plasma etching. For 15 or 20 minute etching times the colloidal mask is entirely removed from the surface. PET is heavily etched by this point and the diameter of the nanostructures is so small that they begin to fuse and form brush-like structures.

Figure 4 shows the evolution of tip width and aspect ratio (feature height/base diameter) for the $500 \mathrm{~nm}$ or $200 \mathrm{~nm}$ colloidal mask surfaces with increasing etching time. In all cases increasing the duration of the ICP-RIE process leads to an increase in aspect ratio. The trend is to increase in height and decrease in base width. Although the height of the 20 minute etched samples decreases when compared to the 15 minute etched samples, the aspect ratio increases due to a similar base diameter. The etch rate between the $200 \mathrm{~nm}$ colloidal mask and the PET substrate is greater. This leads to structures that have a higher ratio of height to base diameter. When using the $200 \mathrm{~nm}$ mask it is possible to gain structures with far higher aspect ratios than when using the $500 \mathrm{~nm}$ PS spheres as the mask layer. Due to the higher etch rate of the smaller PS spheres, it is also possible to obtain features that exhibit a lower tip width. For example, the tip width of the $200 \mathrm{~nm}$ PS mask samples after 10 minutes etching is $33 \mathrm{~nm}$. This is compared to the equivalent $500 \mathrm{~nm}$ sample which yields a tip width of $280 \mathrm{~nm}$. This is an important structural aspect of these samples and is likely to elicit different cellular responses from bacteria. 

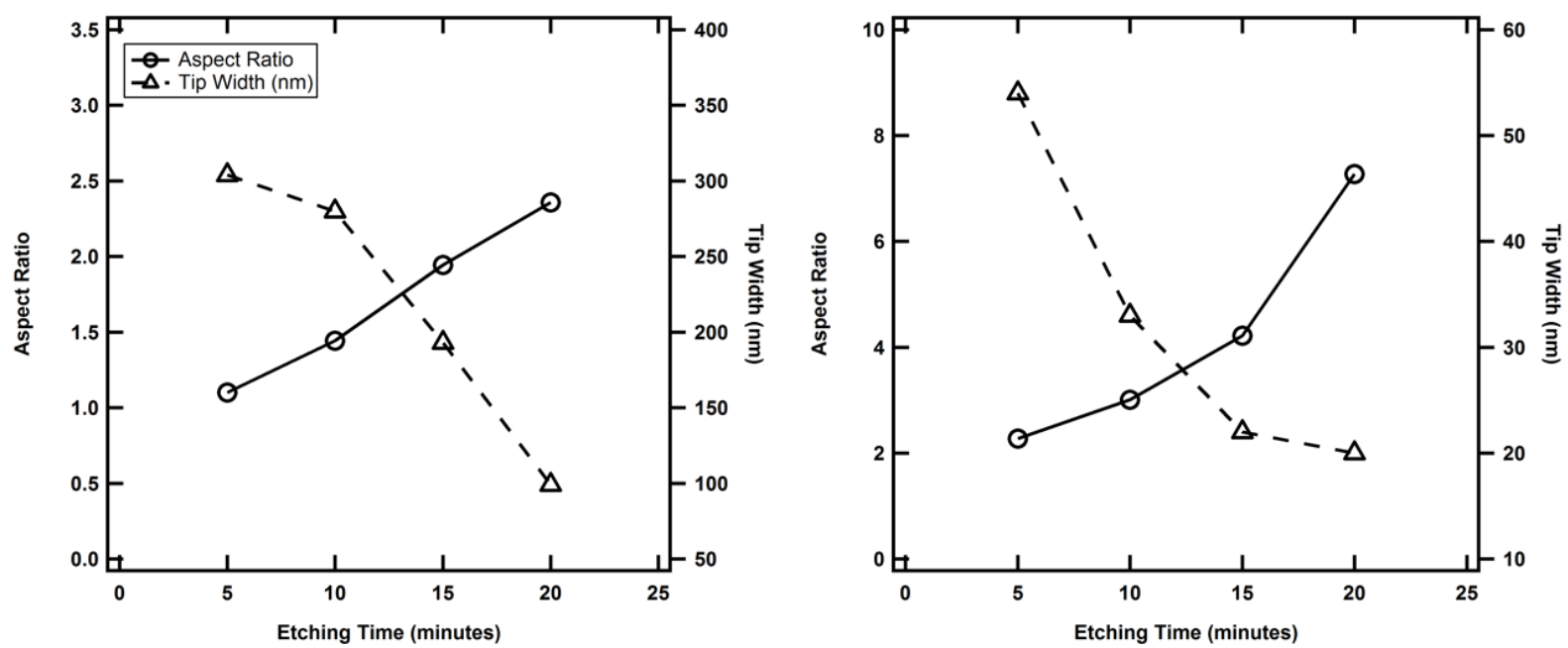

Figure 4- Aspect ratio and tip width evolution of PET nanocones with increased etching times for a $500 \mathrm{~nm}$ (left) or $200 \mathrm{~nm}$ (right) PS colloidal mask.

\section{Surface Wettability}

The wetting of a surface and its associated contact angle is dependent on the chemical makeup and the micro/nano-texture for a given chemical composition ${ }^{49}$. Increasing the roughness of a surface may render it more hydrophilic or hydrophobic depending upon the initial surface properties of the material. Figure 5 shows contact angle measurements taken for surfaces with a 200 and $500 \mathrm{~nm}$ colloidal mask, etched for 5, 10 and 15 minutes. 


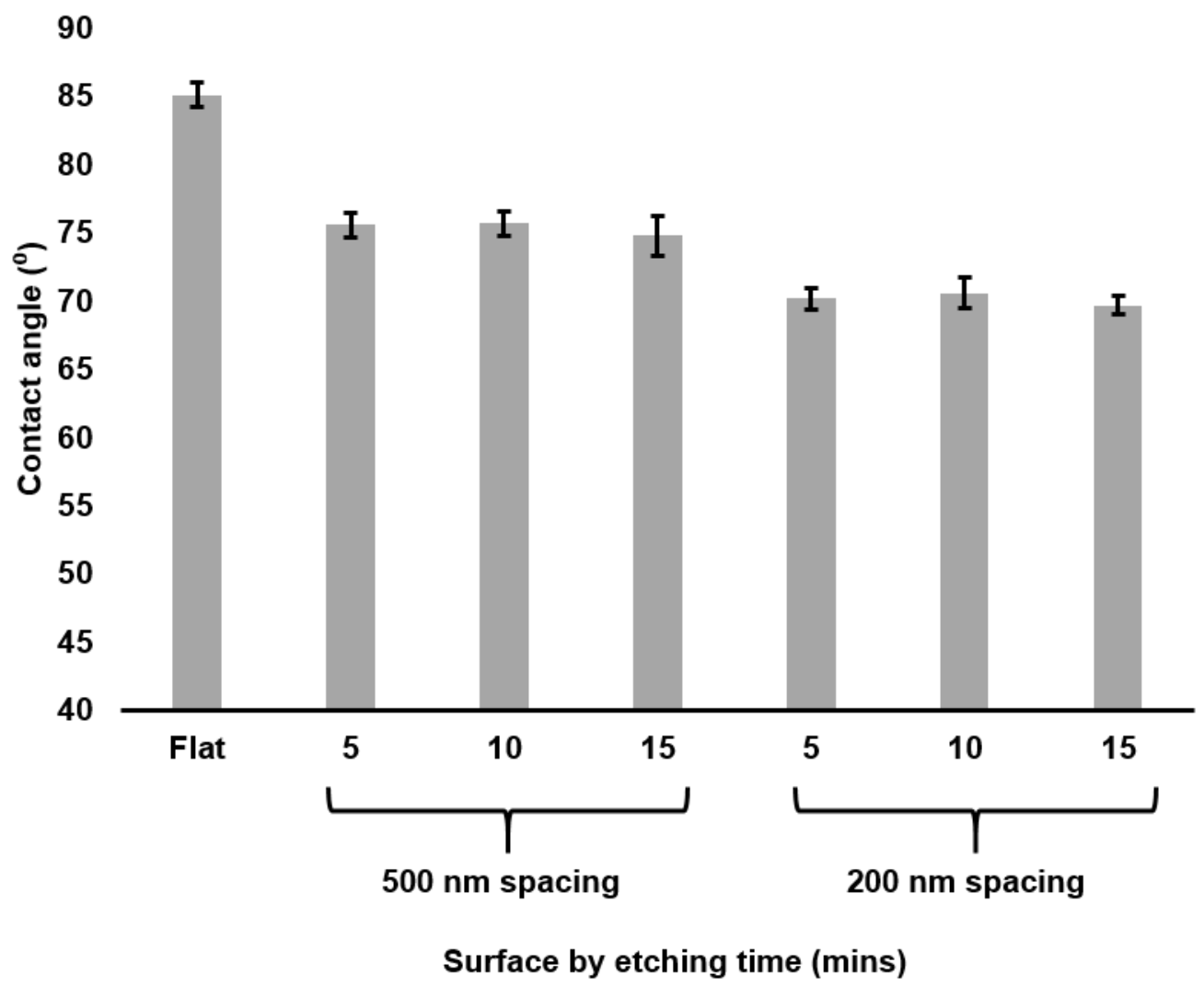

Figure 5- Surface wettability for samples with a $500 \mathrm{~nm}$ and $200 \mathrm{~nm}$ colloidal mask, etched for 5, 10 and 15 minutes.

Flat PET has the highest contact angle of all the surfaces measured here at $85 \pm 2^{0}$. All nanopatterned surfaces exhibit lower contact angles when compared to the flat PET surface. This demonstrates that the RIE process serves to render the interface more hydrophilic with a higher surface energy. There is little difference in surface wettability for individual samples with the same nanopillar spacing. However, samples where nanofeatures are spaced $200 \mathrm{~nm}$ apart have a lower contact angle than those of samples with nanofeatures spaced $500 \mathrm{~nm}$ apart. This shows that denser, more compact nanofeatures yield a lower contact angle and therefore a higher surface energy. It has been shown previously that surfaces with nanofeatures lower than $50 \mathrm{~nm}$ in height are able to trap air locally and render the surface hydrophobic. However, nanofeatures any taller than this nearly always render the surface hydrophilic ${ }^{4,50,51}$. In the case 
of the surfaces fabricated for this study, their high aspect ratio (all above $300 \mathrm{~nm}$ in height) yields surface hydrophilicity. The results reveal that a difference in nanostructure can exert differences in the wetting properties of the surface. The wetting state of the surface was approximated based on two established models: the Wenzel ${ }^{52}$ and the Cassie-Baxter model ${ }^{53}$. The Wenzel model allows that the liquid fills the grooves of the nanostructures and then yields a wetting contact which is found by,

$$
\cos \theta_{w}=r \cos \theta_{0}
$$

where $r$ is the roughness factor (a ratio of the actual surface area to the geometrically projected area), $\theta_{\mathrm{w}}$ is the effective contact angle on a rough surface, and $\theta_{0}$ is the contact angle on a flat surface of the same material. The roughness factor (r) may be calculated by,

$$
r=\frac{(R+L)^{2}+4 R H}{(R+L)^{2}}
$$

where $\mathrm{R}, \mathrm{L}$ and $\mathrm{H}$ are the diameter, spacing and height of the nanofeatures, respectively.

The Cassie model allows that air is trapped in the concave areas of the sample and a contact angle of $180^{\circ}$ is attributed to these air pockets. The effective contact angle of the nanostructured surface is calculated by,

$$
\cos \theta_{c}=\varphi\left(1+\cos \theta_{0}\right)-1,
$$

in which $\theta_{\mathrm{c}}$ is the effective contact angle as described by the model and $\theta_{0}$ is the measured contact angle on an equivalent flat surface. $\varphi$ is the solid fraction in contact with the liquid and is calculated by,

$$
\varphi=\frac{R^{2}}{(R+L)^{2}},
$$


where $\mathrm{R}$ is the diameter of nanofeatures and $\mathrm{L}$ is the spacing of nanofeatures.

As a consequence of these two models and starting from a material with a contact angle below $90^{\circ}$, the Wenzel model will predict a decrease in $\theta$ with increased roughness, while the Cassie model will always predict an increase in $\theta$.

In accordance with both of these models, the roughness factor, solid fraction in contact with the liquid and effective contact angles were calculated and are shown in table 2. Nanocones spaced $200 \mathrm{~nm}$ apart are slightly more hydrophilic than those spread $500 \mathrm{~nm}$ apart. The nanofeatures generated using the $200 \mathrm{~nm}$ colloidal mask are generally shorter than those generated with the $500 \mathrm{~nm}$ mask. These regions with shorter protuberance may facilitate the wetting process and fill with water first, partially or completely wetting the surface under the water droplet ${ }^{54}$. According to the experimental values obtained, and in comparison with the effective contact angles calculated for the Wenzel and Cassie models found in table 2, the Wenzel model best describes the behaviour of the water droplet on the surface. This is due to the fact that the contact angle, $\theta$, decreases with increasing roughness. Although a combination of both Wenzel and Cassie states cannot be ruled out ${ }^{55}$.

\begin{tabular}{|c|c|c|c|c|c|c|}
\hline & \multicolumn{5}{|c|}{ Colloidal Mask Diameter (nm) } \\
\hline & \multicolumn{4}{|c|}{500} & \multicolumn{3}{c|}{200} \\
\cline { 2 - 7 } & \multicolumn{2}{|c|}{ Etching Time (mins) } & \multicolumn{3}{c|}{ Etching Time (mins) } \\
\cline { 2 - 7 } & 5 & 10 & 15 & 5 & 10 & 15 \\
\hline $\begin{array}{c}\varphi, \text { solid fraction in } \\
\text { contact with liquid }\end{array}$ & 0.19 & 0.15 & 0.12 & 0.19 & 0.15 & 0.14 \\
\hline$r$, roughness factor & 1.82 & 1.87 & 1.97 & 2.73 & 2.85 & 3.32 \\
\hline Contact angle (deg) & 75.6 & 75.7 & 74.8 & 70.2 & 70.6 & 69.7 \\
\hline $\begin{array}{c}\text { Effective contact angle } \\
\text { (Wenzel) }\end{array}$ & 80.9 & 80.6 & 80.1 & 76.2 & 75.6 & 73.2 \\
\hline $\begin{array}{c}\text { Effective contact angle } \\
\text { (Cassie-Baxter) }\end{array}$ & 142.5 & 146.8 & 150.4 & 142.5 & 146.8 & 148.0 \\
\hline
\end{tabular}

Table 2- Contact angles, effective contact angles (Cassie-Baxter and Wenezel), solid fraction in contact with the liquid and roughness factor values for PET nanocone structures obtained from a $500 \mathrm{~nm}$ or $200 \mathrm{~nm}$ PS colloidal mask after 5, 10, 15 and 20 minutes of etching time. 


\section{Topographical effects on bacterial viability}

Currently, there are no reports on the effects of biomimetic PET nanocones on bacterial viability. E. coli is a motile, rod-shaped, Gram negative bacterium, and is a commonly isolated microorganism from sites of nosocomial infections ${ }^{56}$. E. coli is a versatile bacterium ranging from harmless gut commensal to extra-intestinal pathogenic strains. It is a common coloniser of medical devices such as catheters where it is responsible for complicated catheter associated urinary tract infections $s^{57,58,59}$. It has also shown resistance to some antimicrobial therapies ${ }^{60}$. $K$. pneumoniae is a non-motile, rod-shaped bacterium. It is a major cause of nosocomial infections, primarily among immunocompromised patients ${ }^{61}$ and is also able to colonise the surface of polymeric devices ${ }^{62}$. Recently, the threat posed by K. pneumoniae has markedly increased due to the emergence of strains resistant to carbapenem antibiotics ${ }^{63}$ and the bacterial pathogen is responsible for around $15 \%$ of Gram-negative infections in intensive care units ${ }^{64}$. Previous work has shown that some nanostructures exhibit a greater bactericidal effect on Gram negative bacterial cells when compared to Gram positive cells ${ }^{35}$. It is suggested that this is due to the thickness of the bacterial cell wall. A large majority of Gram positive bacterial cells have a thicker cell wall with a layer of peptidoglycan that is between 20 and $80 \mathrm{~nm}$ thick. In contrast the peptidoglycan layer of most Gram negative cell walls is much thinner at around 5 to $10 \mathrm{~nm}$ in thickness ${ }^{65}$. It is therefore posited that less stress is required to disrupt the cell wall of Gram negative bacteria, resulting in cell death from purely physical cues ${ }^{37}$. It has also been argued that bacterial motility may play a role in the observed bactericidal effect of a nano-undulating surface, with highly motile bacteria having a higher death rate on the surface ${ }^{35}$. For these reasons, E. coli and K. pneumoniae were used as the model bacterium to test the bactericidal efficacy of the PET nanocone surfaces. 
Surfaces etched for 5, 10 or 15 minutes were exposed to high numbers (approximately $10^{7}$ cfu $\mathrm{ml}^{-1}$ ) of exponential phase E. coli and K. pneumoniae for 1 hour and the bactericidal efficacy of the surfaces was measured using Live/Dead staining. Representative fluorescence micrographs are shown in Figure 6. Here, cells with intact membranes are stained green and cells with damaged membranes are stained in red.
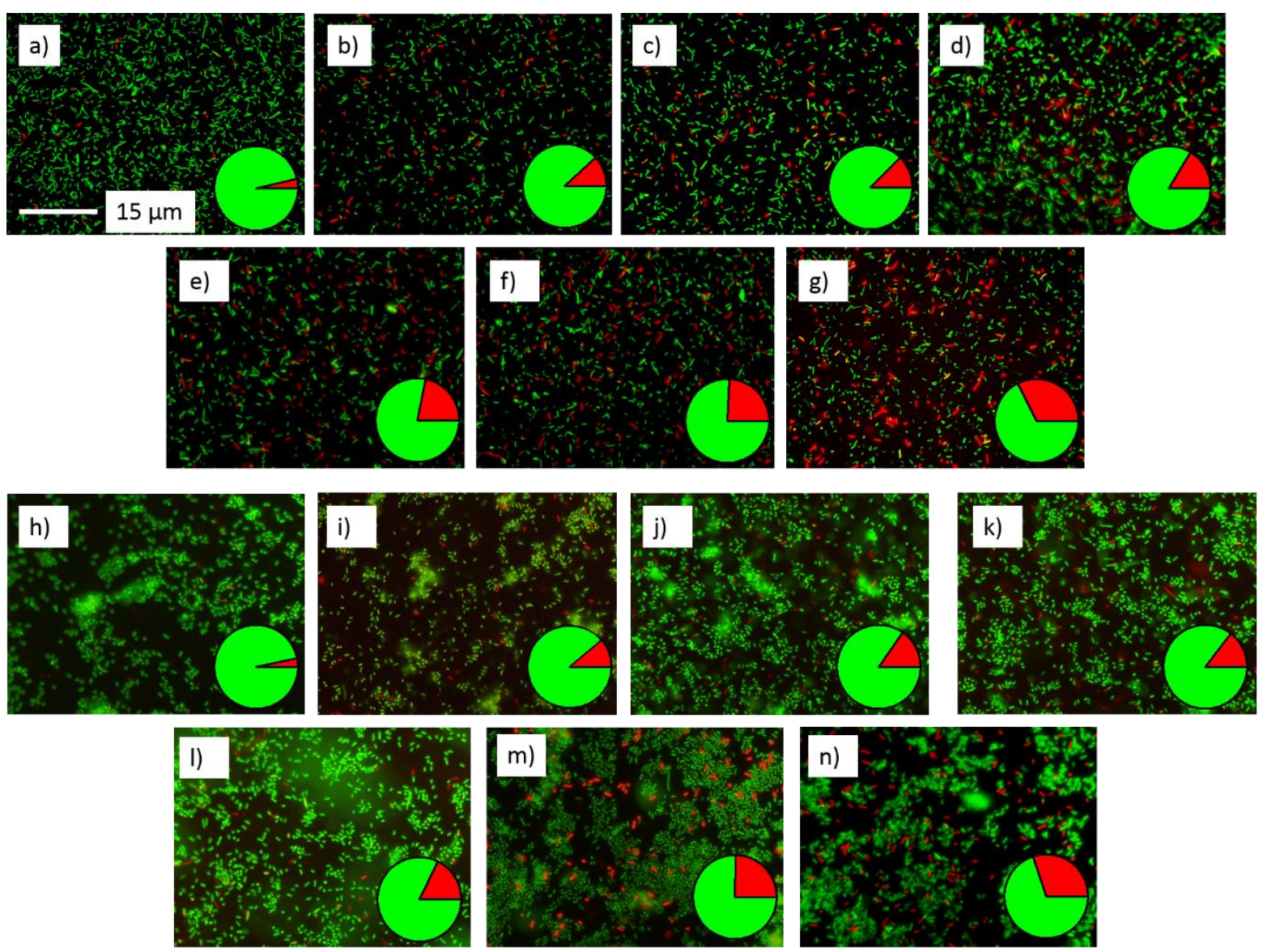

Figure 6- Representative fluorescence micrographs of E. coli and K. pneumoniae after 1 hour incubation on a, h) control flat PET, $500 \mathrm{~nm}$ colloidal mask after etching periods of 5, 10 or 15 minutes (b, c d and i, j, k respectively), or $200 \mathrm{~nm}$ colloidal mask after etching periods of 5, 10 or 15 minutes (e, f g and $1, \mathrm{~m}, \mathrm{n}$ respectively). Bacterial cells were stained with Live/Dead BacLight. Stained cells with intact membranes fluoresce green (SYTO 9) and cells with damaged membranes fluoresce red (propidium iodide). Pie charts represent the percentages of live and dead cells (green and red respectively). 
From analysis of the fluorescence micrographs in Figure 6 it is clear that attachment of bacteria to the PET nanocone surfaces results in statistically significant killing of bacteria when compared to the flat control surface. The percentage of stained dead cells on all surfaces tested in this study (compared to a flat control surface) is shown in Figure 7.
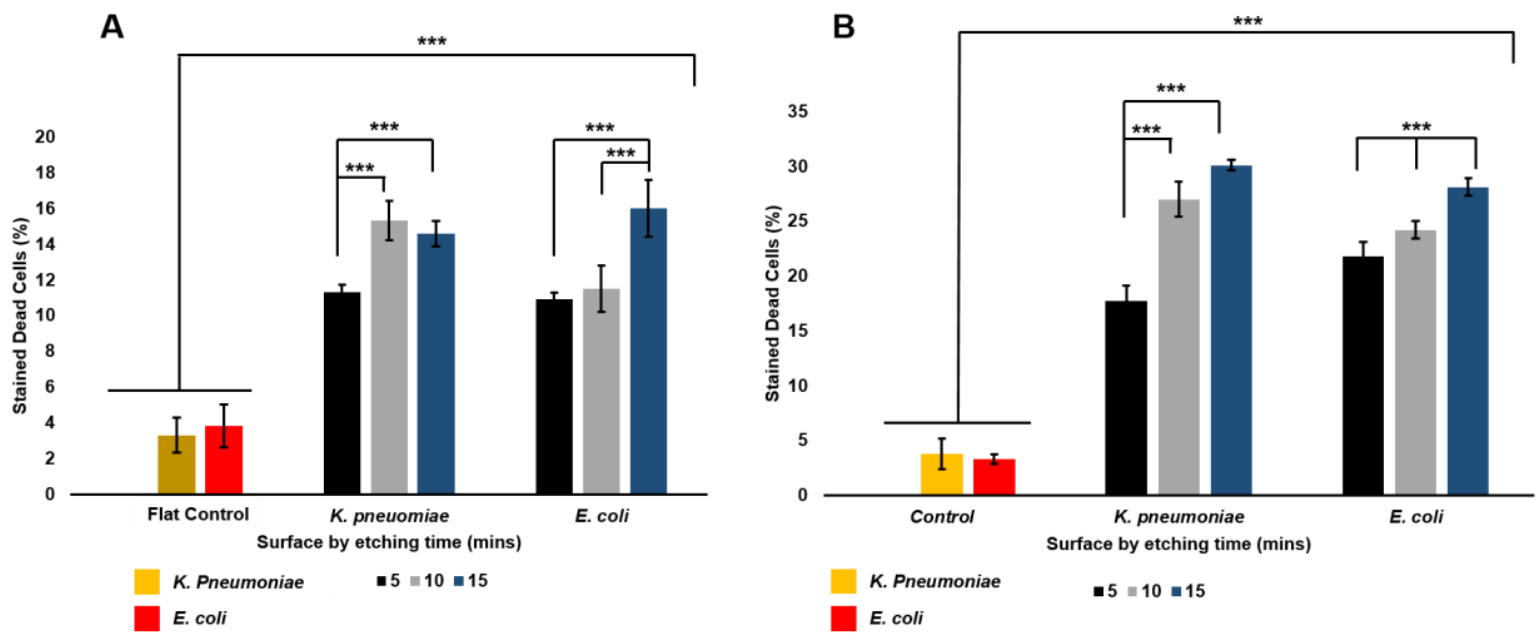

Figure 7- Percentage dead cells after 1 hour incubation of E. coli and K. pneumoniae on PET nanocones formed with a $500 \mathrm{~nm}$ (A) or $200 \mathrm{~nm}$ (B) colloidal mask along with flat control PET surfaces. Bacterial cell viability was determined by Live/Dead BacLight stain.

From analysis of Figure 7 all nanopatterned surfaces result in statistically significant bacterial killing compared to the flat control surface (percentage dead cells on control surface $\sim 3 . \%$ ). Generally, the surfaces with a higher density of nanocones appear to kill the most bacteria. For example, at a constant etching time of 10 minutes, the percentage stained dead E. coli on surfaces formed with the $500 \mathrm{~nm}$ colloidal mask is around $12 \%$ of the surface inoculum. This is compared to the $200 \mathrm{~nm}$ colloidal mask at the same etching duration which kills around $24 \%$ of adherent E. coli. The same is also shown for $K$. pneumoniae with $15 \%$ of adherent cells dead on the equivalent $500 \mathrm{~nm}$ surface, compared to the $200 \mathrm{~nm}$ surface, which has $27 \%$ dead cells. This is the case for all etching durations when comparing surfaces generated with the 500 $\mathrm{nm}$ or $200 \mathrm{~nm}$ colloidal mask. Indeed this conclusion is supported by a study by Kelleher ${ }^{29}$ et 
$a l$ where it was shown that the greater the number of nanostructures with which bacterial cells come into contact, the greater the bactericidal activity. It is also corroborated by the work of Dickson $^{42}$ et al who conducted studies using E. coli on PMMA nanopatterned surfaces. Here, researchers reported that smaller more closely spaced polymer nanopillars had the best performance.

Height, base diameter and tip width are displayed in table 1. The height of the PET nanocones varies dependent on the diameter of the colloidal mask and the etching time employed. There does not appear to be a direct correlation between feature height and bactericidal efficacy. The tallest nanocone is found for the $500 \mathrm{~nm}$ colloidal mask and 15 minute etching time $(529 \mathrm{~nm}$ in height). This induces a percentage cell death of around 14 and $16 \%$ for E. coli and $K$. pneumoniae, respectively. However, the second tallest nanofeature found for the $200 \mathrm{~nm}$ mask and 15 minute etch (498 $\mathrm{nm}$ in height) kills around $30 \%$ of adherent cells. Whilst the shortest nanocones found for the $200 \mathrm{~nm}$ mask and 5 minute etching period (352 nm in height) kill around $20 \%$ of adherent cells. Nanofeature height above a certain value may not play a significant role in the bactericidal efficacy of a surface. Ivanova et $a l^{22}$ have measured the rate at which bacteria cells sink between nanopillars using point force microscopy. They showed that bacteria cells move slowly downwards and sink onto the nanopillars. The bacteria cells were shown to sink by around $200 \mathrm{~nm}$ before a sudden, short, downward displacement indicating the point of membrane rupture. This may imply that there is a certain 'critical' height required to induce membrane rupture. This is also supported by the work of Dickson et al who also observed that height was not a critical factor in efficient bactericidal activity ${ }^{42}$. For individual sample sub-sets generated with the $500 \mathrm{~nm}$ and $200 \mathrm{~nm}$ colloidal mask, the base diameter and tip width decreases with an increase in etching time. The $500 \mathrm{~nm}$ mask samples show tip widths between $300-99 \mathrm{~nm}$ for 5, 10 and 15 minute etching periods. Whereas, the $200 \mathrm{~nm}$ mask samples show tip widths between $54-20 \mathrm{~nm}$. The same trend is also observed 
for base diameter with the 500 and $200 \mathrm{~nm}$ showing base diameter ranges of $380-187 \mathrm{~nm}$ and $155-55 \mathrm{~nm}$, respectively. The general trend is for bactericidal efficacy to increase within individual sample sets as tip width and base diameter are reduced. This corroborates recent results reported by Nowlin ${ }^{66}$ et al whereby the fungicidal properties of surfaces with differing nano-morphologies were investigated. Their results suggest that the fate of a microbe on a surface is heavily dependent on such nano-morphology. It was shown that even weakly adhering strains of fungus Saccharomyces cerevisiae were rendered non-viable when exposed to nanopillars with the smallest diameters. This is also supported by a recent model from Xue $\mathrm{e}^{30}$ et al, in which smaller, sharper nanofeatures are shown to be a key factor in regulating bacterial cell fate on a surface. It was found that smaller, sharper nanofeatures result in a much greater stretching response from the bacteria resting on them and therefore a higher percentage of bacterial death.

One clear conclusion that may be drawn is the surfaces with a higher density of nanocones appear to kill the most bacteria. In $1 \mu \mathrm{m}^{2}$ there will be 4 and 25 nanocones for the $500 \mathrm{~nm}$ and $200 \mathrm{~nm}$ colloidal mask, respectively. Therefore, bacteria in contact with the $200 \mathrm{~nm}$ mask samples will come into contact with $\sim 6$ times as many nanofeatures when compared to bacteria in contact with the $500 \mathrm{~nm}$ mask samples. At a constant etching time of 10 minutes, the percentage stained dead E. coli on surfaces formed with the $500 \mathrm{~nm}$ colloidal mask is around $12 \%$ of the surface inoculum. This is compared to the $200 \mathrm{~nm}$ colloidal mask at the same etching duration which kills around $24 \%$ of adherent $E$. coli. The same is also shown for $K$. pneumoniae with $15 \%$ of adherent cells dead on the equivalent $500 \mathrm{~nm}$ surface, compared to the $200 \mathrm{~nm}$ surface, which has $27 \%$ dead cells. This is the case for all etching durations when comparing surfaces generated with the $500 \mathrm{~nm}$ or $200 \mathrm{~nm}$ colloidal mask. Indeed this conclusion is supported by a study by $\operatorname{Kelleher}^{29}$ et al where it was shown that the greater the number of nanostructures with which bacterial cells come into contact, the greater the 
bactericidal activity. This idea is again corroborated by Dickson ${ }^{42}$ et al where it was shown that feature spacing of $100 \mathrm{~nm}$ killed $\sim 20 \%$ more bacteria than surfaces with feature spacings of $380 \mathrm{~nm}$.

These phenomena are also shown in figure 8 in a series of SEM images. Cells were fixed after $1 \mathrm{~h}$ incubation with bacterial suspensions. Images exhibited horizontal, turgid cells on the flat control surfaces, correlating with the fluorescence microscopy results. On the nanopatterned surfaces, many of the cells appeared to display undamaged morphology. However, a proportion appeared to display a damaged morphology as a result of the nanofeatures. It is clear that the nanotopography damages a higher percentage of the cells as shown by fluorescence microscopy. The cells collapse and spread over the surfaces which is a visible indicator of nonrecoverable cell death ${ }^{37}$ 

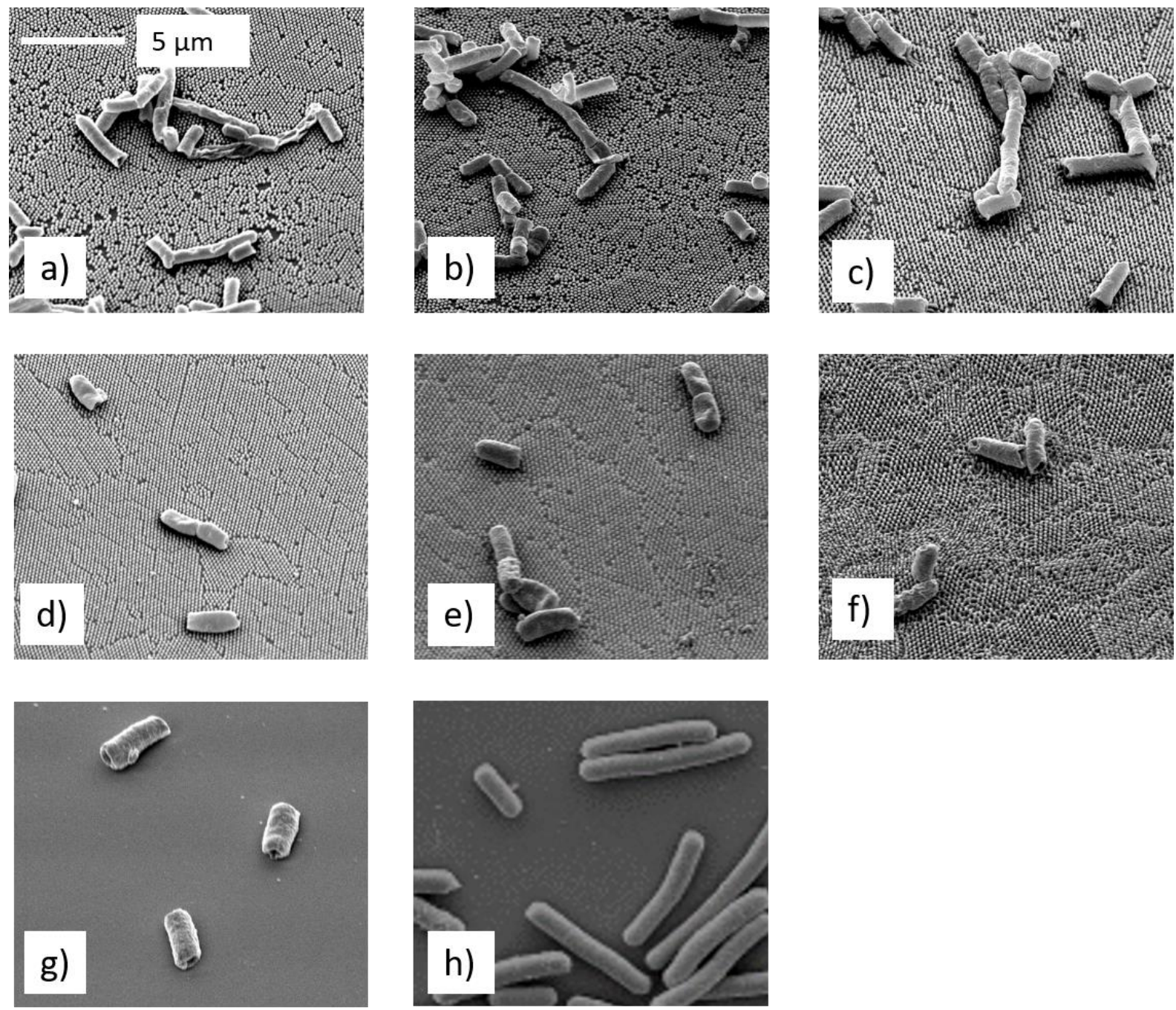

Figure 8- SEM images showing E. coli and $K$. pneumoniae on PET nanocone surfaces with a $500 \mathrm{~nm}$ colloidal mask etched for 5, 10 and 15 minutes (a, b and c) and a $200 \mathrm{~nm}$ colloidal mask etched for 5, 10 and 15 minutes (d, e and f). Also shown are the E. coli and K. pneumoniae on a flat control surface ( $\mathrm{g}$ and $\mathrm{h}$ ).

All PET nanocone test surfaces were successfully shown to elicit bactericidal capabilities. Thus these surfaces have the potential to reduce bacterial colonisation of medical devices. One vital aspect for future work will be the tunability of nanofeatures on a surface ${ }^{67}$; a feature that this protocol allows for. It is clear from this study and others that nanofeature shape and size, as well as distribution and density, play a key role in the fate of microbes on a surface. Another important parameter that may affect the viability of the bacteria on these surfaces is the 
concentration of the polystyrene mask that remains after etching. For samples etched for longer periods of time this is unlikely to be a key factor in determining bacterial cell fate as the mask is entirely removed. However, for surfaces with lower etching times it must be accepted that residual mask may play a role in governing bacterial adhesion and viability. This will be an important avenue of investigation in future studies. The highest levels of bacterial cell death observed here are $~ 30 \%$. In order for these materials to be clinically appropriate or for use in long-term biomedical implants, they would need to kill much higher percentages of bacteria. Other key questions within the research field are what happens to the dead bacteria that remain on the surface and is the bactericidal effect observed only transient? These are critical elements that must be considered when engineering surfaces for such applications. However, the results presented here chart a course for optimization and may be built upon in future studies that are likely to provide answers to these questions. It is clear that on closely spaced, sharp tipped nanocones, there is a higher level of bacterial cell death. Smaller tip radii generate higher stress fields on the bacterial membrane, which increases the chances of rupture ${ }^{30,42}$. It may be hypothesised that increasing the nanocone density even further may result in higher bactericidal efficacies. There is also the possibility of functionalising PET nanocones with bactericidal molecules to promote synergistic killing of bacteria through both chemical and mechanical means $^{68,69}$.

\section{Conclusions}

Biomimetic analogues of the cicada wing were fabricated on the surface of PET using colloidal lithography. This study has expanded upon previously fabricated polymer nanocone structures $^{37,42,45,70}$ generating surfaces with differing/tailorable nanofeature spacing, height, base diameter and tip widths. It is also the first study to examine the bactericidal efficacy of 
PET nanocones and to assess bactericidal performance against nanostructural parameters. All surfaces generated showed statistically significant higher levels of bactericidal activity against E. coli and K. pneumoniae when compared to a flat control surface.It was shown that surfaces with denser nanotopographical features, higher aspect ratios and sharper tips exhibit higher levels of bacterial killing. These results act to expand upon our understanding of the effect of differing nanotopography and bactericidal performance $29,30,41$. To allow this study to be extended to a clinical setting, future research will need to demonstrate that these surfaces can kill a broader range and higher percentage of microorganisms whilst also eliciting appropriate responses from mammalian cells ${ }^{32}$. However, this study shows that PET nanocones engineered through a cost-effective fabrication technique can serve to kill adherent bacterial cells and may pave the way for the generation of new types of biomaterials with the ability to reduce the risk of infections associated with medical devices.

\section{AUTHOR INFORMATION}

*Corresponding author: g.hazell@ chester.ac.uk

\section{Acknowledgements}

The authors would like to thank the EPSRC Bristol Bridge Award (Bridging the Gaps between the Engineering and Physical Sciences and Antimicrobial Resistance (EP/M027546/1)) and the MRC (Innovation Grant (MR/N010345/1)) for funding. We thank A. Edwards for the provision of $E$. coli $\mathrm{K} 12$. 


\section{References}

1. Busscher, H. J.; van der Mei, H. C.; Subbiahdoss, G.; Jutte, P. C.; van den Dungen, J.; Zaat, S. A.; Schultz, M. J.; Grainger, D. W. Biomaterial-associated infection: Locating the finish line in the race for the surface. Science Translational Medicine 2012, 4 (153), 153.

2. Stewart, P. S.; Costerton, J. W. Antibiotic resistance of bacteria in biofilms. Lancet 2001, 358 (9276), 135-138.

3. Pulido, L.; Ghanem, E.; Joshi, A.; Purtill, J. J.; Parvizi, J. Periprosthetic joint infection: The incidence, timing and predisposing factors. Clinical orthopaedics and related research 2008, 466 (7), 1710-1715.

4. Campoccia, D.; Montanaro, L.; Arciola, C. R. A review of the biomaterials technologies for infection resistant surfaces. Biomaterials 2013, 34 (34), 8533-8534.

5. Suhardi, V. J.; Bichara, D. A.; Kwok, S. J. J.; Freiberg, A. A.; Rubash, H.; Malchau, H.; Yun, S. H.; Muratoglu, O. K.; Oral, E. A fully functional drug-eluting joint implant. Nature Biomedical Engineering 2017, 1, 0080.

6. Zhao, L.; Chu Paul, K.; Zhang, Y.; Wu, Z. Antibacterial coatings on titanium implants. Journal of Biomedical Materials Research Part B: Applied Biomaterials 2009, 91B (1), 470-480.

7. Taglietti, A.; Arciola, C. R.; D'Agostino, A.; Dacarro, G.; Montanaro, L.; Campoccia, D.; Cucca, L.; Vercellino, M.; Poggi, A.; Pallavicini, P.; Visai, L. Antibiofilm activity of a monolayer of silver nanoparticles anchored to an amino-silanized glass surface. Biomaterials 2014, 35 (6), 1779-1788.

8. Xiu, Z.-m.; Zhang, Q.-b.; Puppala, H. L.; Colvin, V. L.; Alvarez, P. J. J. Negligible Particle-Specific Antibacterial Activity of Silver Nanoparticles. Nano Letters 2012, 12 (8), 4271-4275.

9. Zhao, Y.; Tian, Y.; Cui, Y.; Liu, W.; Ma, W.; Jiang, X. Small Molecule-Capped Gold Nanoparticles as Potent Antibacterial Agents That Target Gram-Negative Bacteria. Journal of the American Chemical Society 2010, 132 (35), 12349-12356.

10. Murata, H.; Koepsel, R. R.; Matyjaszewski, K.; Russell, A. J. Permanent, non-leaching antibacterial surfaces-2: How high density cationic surfaces kill bacterial cells. Biomaterials 2007, 28 (32), 4870-4879.

11. Yang, W. J.; Cai, T.; Neoh, K.-G.; Kang, E.-T.; Dickinson, G. H.; Teo, S. L.-M.; Rittschof, D. Biomimetic Anchors for Antifouling and Antibacterial Polymer Brushes on Stainless Steel. Langmuir 2011, 27 (11), 7065-7076.

12. Song, J.; Jang, J. Antimicrobial polymer nanostructures: Synthetic route, mechanism of action and perspective. Advances in Colloid and Interface Science 2014, 203, 37-50.

13. Kazemzadeh-Narbat, M.; Kindrachuk, J.; Duan, K.; Jenssen, H.; Hancock, R. E. W.; Wang, R. Antimicrobial peptides on calcium phosphate-coated titanium for the prevention of implantassociated infections. Biomaterials 2010, 31 (36), 9519-9526.

14. Costa, F.; Carvalho, I. F.; Montelaro, R. C.; Gomes, P.; Martins, M. C. L. Covalent immobilization of antimicrobial peptides (AMPs) onto biomaterial surfaces. Acta Biomaterialia 2011, 7 (4), 1431-1440.

15. Minier, M.; Salmain, M.; Yacoubi, N.; Barbes, L.; Méthivier, C.; Zanna, S.; Pradier, C.-M. Covalent Immobilization of Lysozyme on Stainless Steel. Interface Spectroscopic Characterization and Measurement of Enzymatic Activity. Langmuir 2005, 21 (13), 5957-5965.

16. Yeroslavsky, G.; Girshevitz, O.; Foster-Frey, J.; Donovan, D. M.; Rahimipour, S. Antibacterial and Antibiofilm Surfaces through Polydopamine-Assisted Immobilization of Lysostaphin as an Antibacterial Enzyme. Langmuir 2015, 31 (3), 1064-1073.

17. Reidy, B.; Haase, A.; Luch, A.; Dawson, K.; Lynch, I. Mechanisms of Silver Nanoparticle Release, Transformation and Toxicity: A Critical Review of Current Knowledge and Recommendations for Future Studies and Applications. Materials 2013, 6 (6), 2295.

18. Stewart, P. S. Mechanisms of antibiotic resistance in bacterial biofilms. International Journal of Medical Microbiology 2002, 292 (2), 107-113. 
19. Mah, T.-F. C.; O'Toole, G. A. Mechanisms of biofilm resistance to antimicrobial agents. Trends in Microbiology 2001, 9 (1), 34-39.

20. Tripathy, A.; Sen, P.; Su, B.; Briscoe, W. H. Natural and bioinspired nanostructured bactericidal surfaces. Advances in Colloid and Interface Science 2017, 248, 85-104.

21. Elbourne, A.; Crawford, R. J.; Ivanova, E. P. Nano-structured antimicrobial surfaces: From nature to synthetic analogues. Journal of Colloid and Interface Science 2017, 508, 603-616.

22. Ivanova, E. P.; Hasan, J.; Webb, H. K.; Truong, V. K.; Watson, G. S.; Watson, J. A.; Baulin, V. A.; Pogodin, S.; Wang, J. Y.; Tobin, M. J.; Lobbe, C.; Crawford, R. J. Natural bactericidal surfaces: mechanical rupture of Pseudomonas aeruginosa cells by cicada wings. Small 2012, 8 (16), 24892494.

23. Hasan, J.; Webb, H. K.; Truong, V. K.; Watson, G. S.; Watson, J. A.; Tobin, M. J.; Gervinskas, G.; Juodkazis, S.; Wang, J. Y.; Crawford, R. J.; Ivanova, E. P. Spatial Variations and Temporal Metastability of the Self-Cleaning and Superhydrophobic Properties of Damselfly Wings. Langmuir 2012, 28 (50), 17404-17409.

24. Bandara, C. D.; Singh, S.; Afara, I. O.; Wolff, A.; Tesfamichael, T.; Ostrikov, K.; Oloyede, A. Bactericidal effects of natural nanotopography of dragonfly wing on escherichia coli. ACS Applied Materials and Interfaces 2017, 9 (8), 6746-6760.

25. Mann, E. E.; Manna, D.; Mettetal, M. R.; May, R. M.; Dannemiller, E. M.; Chung, K. K.; Brennan, A. B.; Reddy, S. T. Surface micropattern limits bacterial contamination. Antimicrobial resistance and infection control 2014, 3 (28), 2-8.

26. Ma, J.; Sun, Y.; Gleichauf, K.; Lou, J.; Li, Q. Nanostructure on Taro Leaves Resists Fouling by Colloids and Bacteria under Submerged Conditions. Langmuir 2011, 27 (16), 10035-10040.

27. Hasan, J.; Webb, H. K.; Truong, V. K.; Pogodin, S.; Baulin, V. A.; Watson, G. S.; Watson, J. A.; Crawford, R. J.; Ivanova, E. P. Selective bactericidal activity of nanopatterned superhydrophobic cicada Psaltoda claripennis wing surfaces. Environmental biotechnology 2013, 97, 9257-9262.

28. Pogodin, S.; Hasan, J.; Baulin, V. A.; Webb, H. K.; Truong, V. K.; Hong, T.; Nguyen, P.; Boshkovikj, V.; Fluke, C. J.; Watson, G. S.; Watson, J. A.; Crawford, R. J.; Ivanova, E. P. Biophysical model of bacterial cell interactions with nanopatterned cicada wing surfaces. Biophysical Journal 2013, 104 (4), 835-840S.

29. Kelleher, S. M.; Habimana, O.; Lawler, J.; O' Reilly, B. O.; Daniels, S.; Casey, E.; Cowley, A. Cicada wing surface topography: An investigation into the bactericidal properties of nanostructural features. ACS Applied Materials and Interfaces 8, 14966-14974.

30. Xue, F.; Liu, J.; Guo, L.; Zhang, L.; Li, D.; Li, Q. Theoretical study on the bactericidal nature of nanopatterned surfaces. Journal of theoretical biology 2015, 385 (21), 1-7.

31. Truong, V. K.; Webb, H. K.; Fadeeva, E.; Cichkov, B. N.; Wu, A. H. F.; Lamb, R.; Wang, J. Y.; Crawford, R. J.; Ivanova, E. P. Air-directed attachment of coccoid bacteria to the surface of superhydrophobic lotus-like titanium. The journal of bioadhesion and biofilm research 2012, 28 (6), 539-550.

32. Bhadra, C. M.; Khanh Truong, V.; Pham, V. T. H.; Al Kobaisi, M.; Seniutinas, G.; Wang, J. Y.; Juodkazis, S.; Crawford, R. J.; Ivanova, E. P. Antibacterial titanium nano-patterned arrays inspired by dragonfly wings. Scientific Reports 2015, 5, 16817.

33. Tsimbouri, P. M.; Fisher, L.; Holloway, N.; Sjostrom, T.; Nobbs, A. H.; Meek, R. M. D.; Su, B.; Dalby, M. J. Osteogenic and bactericidal surfaces from hydrothermal titania nanowires on titanium substrates. Scientific Reports 2016, 6, 36857.

34. Hizal, F.; Zhuk, I.; Sukhishvili, S.; Busscher, H. J.; van der Mei, H. C.; Choi, C.-H. Impact of 3D Hierarchical Nanostructures on the Antibacterial Efficacy of a Bacteria-Triggered Self-Defensive Antibiotic Coating. ACS Applied Materials \& Interfaces 2015, 7 (36), 20304-20313.

35. Diu, T.; Faruqui, N.; Sjostrom, T.; Lamarre, B.; Jenkinson, H. F.; Su, B.; Ryadnov, M. G. Cicadainspired cell-instructive nanopatterned arrays. Scientific Reports 2014, 4 (7122), 1-7. 
36. Pham, V. T. H.; Truong, V. K.; Quinn, M. D. J.; Notley, S. M.; Guo, Y.; Baulin, V. A.; Al Kobaisi, M.; Crawford, R. J.; Ivanova, E. P. Graphene Induces Formation of Pores That Kill Spherical and RodShaped Bacteria. ACS Nano 2015, 9 (8), 8458-8467.

37. Fisher, L. E.; Yang, Y.; Yuen, M.; Zhang, W.; Nobbs, A. H.; Su, B. Bactericidal activity of biomimetic diamond nanocone surfaces. Biointerphases 2016, 11 (1), 0110141-0110146.

38. May, P. W.; Clegg, M.; Silva, T. A.; Zanin, H.; Fatibello-Filho, O.; Celorrio, V.; Fermin, D. J.; Welch, C. C.; Hazell, G.; Fisher, L.; Nobbs, A. H.; Su, B. Diamond-coated 'black' silicon as a promising material for high-surface-area electrochemical electrodes and antibacterial surfaces. Journal of materials chemistry B 2016, 4, 5737-5746.

39. Sakamoto, A.; Terui, Y.; Horie, C.; Fukui, T.; Masuzawa, T.; Sugawara, S.; Shigeta, K.; Shigeta, T.; Igarashi, K.; Kashiwagi, K. Antibacterial effects of protruding and recessed shark skin micropatterned surfaces of polyacrylate plate with a shallow groove. FEMS Microbiology letters 2014, 361 (1), 10-16.

40. Chung, K. K.; Schumacher, J. F.; Sampson, E. M.; Burne, R. A.; Antonelli, P. J.; Brennan, A. B. Impact of engineered surface microtopography on biofilm formation of staphylococcus aureus. Biointerphases 2007, 2 (2), 89-94.

41. Ivanova, E. P.; Hasan, J.; Webb, H. K.; Gervinskas, G.; Juodkazis, S.; Truong, V. K.; Wu, A. H. F.; Lamb, R. N.; Baulin, V. A.; Watson, G. S.; Watson, J. A.; Mainwaring, D. E.; Crawford, R. J. Bactericidal activity of black silicon. Nature Communications 2013, 4 (2838), 1-7.

42. Dickson, M. N.; Liang, E. I.; Rodriguez, L. A.; Vollereaux, N.; Yee, A. F. Nanopatterned polymer surfaces with bactericidal properties. Biointerphases 2015, 10 (2), 0210101-0210108.

43. Michel, R.; Reviakine, I.; Sutherland, D.; Fokas, C.; Csucs, G.; Danuser, G.; Spencer, N. D.; Textor, M. A Novel Approach To Produce Biologically Relevant Chemical Patterns at the Nanometer Scale: Selective Molecular Assembly Patterning Combined with Colloidal Lithography. Langmuir 2002, 18 (22), 8580-8586.

44. Dalby, M. J.; Riehle, M. O.; Sutherland, D. S.; Agheli, H.; Curtis, A. S. G. Changes in fibroblast morphology in response to nano-columns produced by colloidal lithography. Biomaterials 2004, 25 (23), 5415-5422.

45. Liu, W.; Liu, X.; Fangteng, J.; Wang, S.; Fang, L.; Shen, H.; Xiang, S.; Yang, B. Bioinspired polyethylene terepthalate nanocone arrays with underwater superoleophobicity and antibioadhesion properties. Nanoscale 2014, 6 (22), 13845-13853.

46. Choi, D. G.; Yu, H. K.; Jang, S. G.; Yang, S. M. Colloidal lithographic nanopatterning via reactive ion etching. Journal of the American Chemical Society 2004, 126, 7019-7025.

47. Busscher, H. J.; van der Mei, H. C. Microbial adhesion in flow displacement systems. Clinical microbiology reviews 2006, 19 (1), 127-141.

48. Z Zhang, X.; Zhang, J.; Ren, Z.; Li, X. Z.; Zhang, X. R.; Zhu, D.; Wang, T.; Tian, T.; Yang, B. Morphology and wettability control of silicon cone arrays using colloidal lithography. Langmuir 2009, 25 (13), 7375-7382.

49. Good, R. J. Contact angle, wetting and adhesion: a critical review. Journal of adhesion science and technology 1992, 6 (12), 1269-1302.

50. Lorenzetti, M. e. $a$. The influence of surface modification on bacterial adhesion to titanium based substrates. ACS Applied materials and interfaces 2015, 7 (3), 1644-1651.

51. Lim, H. e. a. Simple nanofabrication of a superhydrophobic and transparent biomimetic surface. Science 2009, 54 (19), 3613-3616.

52. Wenzel, R. N. Resistance of solid surfaces to wetting by water. Industrial and Engineering Chemistry 1936, 28, 988-994.

53. Whyman, G.; Bormashenko, E.; Stein, T. The rigorous derivation of Young, Cassie-Baxter and Wenzel equations and the analysis of the contact angle hysteresis phenomenon. Chemical Physics Letters 2008, 450 (4), 355-359.

54. Sun, M.; Watson, G. S.; Zheng, Y.; Watson, J. A.; Liang, A. Wetting properties on nanostructured surfaces of cicada wings. Journal of Experimental Biology 2009, 212 (19), 3148. 
55. Bico, J.; Thiele, U.; Quéré, D. Wetting of textured surfaces. Colloids and Surfaces A: Physicochemical and Engineering Aspects 2002, 206 (1), 41-46.

56. Bereket, W.; Hemalatha, K.; Getenet, B.; Wondwossen, T.; Solomon, A.; Zeynudin, A.; Kannan, S. Update on bacterial nosocomial infections. european review for medical and pharmacological sciences 2012, 16, 1039-1044.

57. Costerton, J. W.; Stewart, P. S.; Greenberg, E. P. Bacterial biofilms: a common cause of persistent infections. Science 1999, 284, 1318-1322.

58. Beloin, C.; Roux, A.; Ghigo, J. M. Escherichia coli biofilms. Current topics in microbiology and immunology 2008, 322, 249-289.

59. Jacobsen, S. M.; Stickler, D. J.; Mobley, H. L. T.; Shirtliff, M. E. Complicated catheterassociated urinary tract infections due to escherichia coli and proteus mirabilis. Clinical microbiology reviews 2008, 21 (1), 26-59.

60. Karlowsky, J. A.; Kelly, L. J.; Thornsberry, C.; Jones, M. E.; Sahm, D. F. Trends in antimicrobial resistance among urinary tract infection isolates of Escherichia coli from female outpatients in the United States. Antimicrobial agents and chemotherapy 2002, 46 (8), 2540-2545.

61. Snitkin, E. S.; Zelanzy, A. M.; Thomas, P. J.; Stock, F.; Henderson, D. K.; Palmore, T. N.; Segre, J. A. Tracking a hospital outbreak of carbapenem-resistant Klebsiella pneumoniae with wholegenome sequencing. Science Translation Medicine 2012, 4 (148), 116.

62. Murphy, C. N.; Mortensen, M. S.; Krogfelt, K. A.; Clegg, S. Role of klebsiella pneumoniae Type 1 and Type 3 fimbriae in colonizing silicone tubes implanted into the bladders of mice as a model of catheter associated urinary tract infections. Infection and Immunity 2013, 81 (8), 3009-3017.

63. Lockhart, S. R.; Abramson, M. A.; Beekman, S. E.; Gallagher, G.; Riedel, S.; Diekema, D. J.; Quinn, J. P.; Doern, G. V. Antimicronial resistance among Gram-negative bacilli causing infections in intensive care unit patients in the United States between 1993 and 2004. Journal of clinical microbiology 2007, 45, 3352-3359.

64. Yigit, H.; Queenan, A. M.; Anderson, G. J.; Domenech-Sanchez, A.; Biddle, J. W.; Steward, C. D.; Alberti, S.; Bush, K.; Tenover, F. C. Novel carbapenem-hydrolyzing beta-lactamase, KPC-1, from a carbapenem-resistant strain of Klebsiella pneumoniae. Antimicrobial agents and chemotherapy 2001, 45, 1151-1161.

65. Brown, L.; Wolf, J. M.; Prados-Rosales, R.; Casadevall, A. Through the wall: extracellular vesicles in Gram-positive bacteria, mycobacteria and fungi. Nature Reviews Microbiology 2015, 13 , 620-630.

66. Nowlin, K.; Boseman, A.; Covell, A.; LaJeunesse, D. Adhesion-dependent rupturing of Saccharomyces cerevisia on biological antimicrobial nanostructured surfaces. Interface 2015, 12, 112.

67. Sjostrom, T.; Brydone, A. S.; Meek, R. M. D.; Dalby, M. J.; Su, B.; McNamara, L. E. Titanium nanofeaturing for enhanced bioactivity of implanted orthopaedic and dental devices. Nanomedicine 2013, 8 (1), 89-104.

68. Jiang, L.; Marcus, R. K. Bio-functionalized poly(ethylene terepthalate) capillary-channeled polymer fibres as HPLC stationary phase for affinity chromatography. Analytical and bioanalytical chemistry 2015, 407 (3), 939-951.

69. Kwon, H. J.; Jung, C. H.; Hwang, I. T.; Choi, J. H.; Nho, Y. C. Surface functionalization of poly(ethylene terepthalate) for biomolecule immobilization by ion implantation. Journal of the Korean physical society 2009, 54 (5), 2071-2075.

70. Zhang, W.; Lin, G.; Li, J.; Xue, H.; Luo, Y.; Gao, X. Fabrication of Biomimetic Polymer Nanocone Films with Condensate Microdrop Self-Removal Function. Advanced Materials Interfaces 2015, 2 (12), 1500238. 
Graphical Abstract (for table of contents use only)
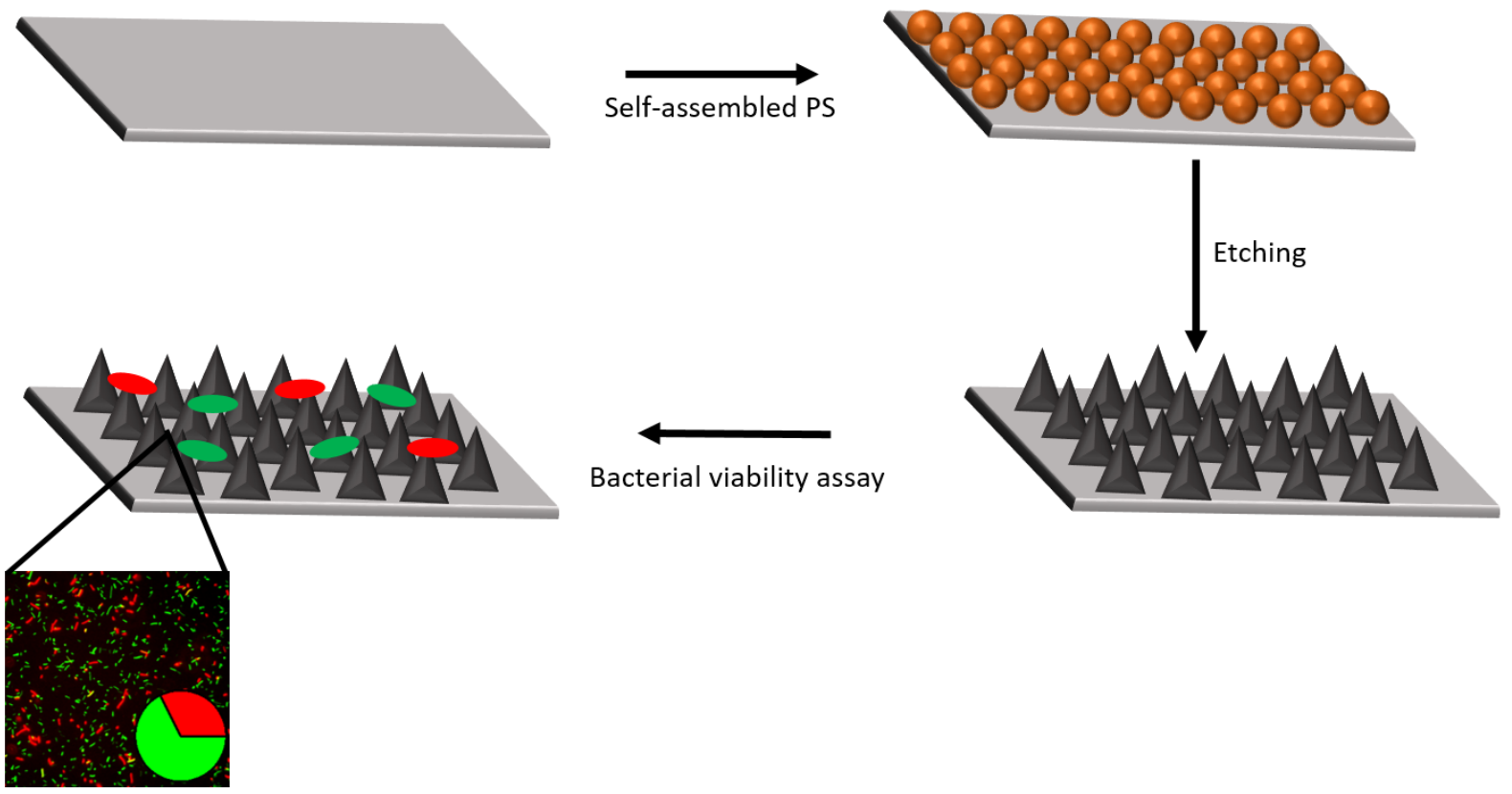